\title{
高周波リンク形 $\mathrm{AC}-\mathrm{DC}$ コンバータの波形制御法
}

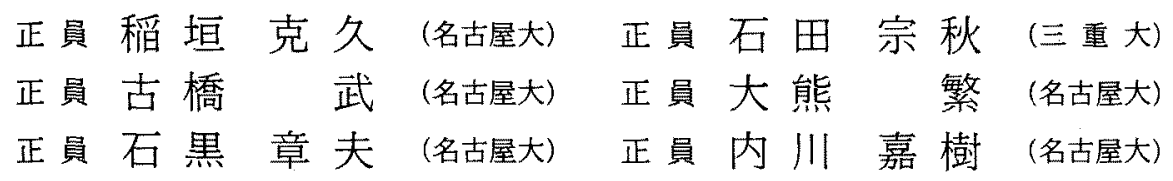

\section{A Waveform Control Method of AC to DC Converters with High-Frequency Links}

Katsuhisa Inagaki, Associate, Takeshi Furuhashi, Member, Akio Ishiguro, Associate (Nagoya University), Muneaki Ishida, Member (Mie University), Shigeru Okuma, Member, Yoshiki Uchikawa, Member (Nagoya University)

Transformer isolation is a usual practice for ohmic isolation between a source and a load. The transformer designed for commercial frequency $(50 / 60 \mathrm{~Hz})$ makes the converter bulky and heavy. Therefore, high-frequency link converters have been studied to make the transformer smaller and to minimize the weight, size and cost of the converters.

This paper presents a new real-time control method of AC to DC converters with high-frequency links (switch mode rectifiers: SMR's). Results are as follows:

(1) The new method makes the switching frequency of the SMR smaller than the conventional method.

(2) The proposed method realizes sinusoidal input current, arbitrary output voltage waveform and controllable input displacement factor. The maximum output voltage ratio to the input liveto-neutral voltage is $3 / 2$.

(3) The new method is suitable for real time control and suppression of DC magnetization of the high-frequency transformer can easily be implemented.

(4) Feasibility of the proposed method is confirmed by simulations and experiments.

Using this method, it is easy to control the voltage waveform of the primary winding of the high-frequency tranformer by changing the output function, so that it is possible to compensate the unbalance of the source voltage and influence of the dead time.

キーワード：高周波リンク，強制転流方式，直接変換

\section{1.はじめに}

近年，商用三相交流から直流を得るコンバータにお いて, 小形・軽量化の要求が高まってきた。半導体電 力変換素子の高性能化扔よびマイコンなどを用いた制 御技術の発達に伴い，スイッチングによる整流回路部 分の小形化は急速に進められているが，電源変圧器の 小形化㹥大きな課題として残されている。その中で, 高周波リンク形 $\mathrm{AC}-\mathrm{DC}$ コンバータは, 絶緑変圧器を
高周波部分に挿入することにより絶緑変圧器の体積・ 重量を著しく小さくできるため，最近注目を集めて いる。

従来提案されてきた高周波リンク形 AC-DC コンバ 一夕只住，商用周波の交流電圧を整流回路により一度 整流して直流電压に変換し，インバータにより高周波 の交流電圧に変換した後, 高周波変圧器を経て再度整 流し負荷に直流を供給している（以下， $\mathrm{AC} \rightarrow \mathrm{DC} \rightarrow$ $\mathrm{HF} \rightarrow \mathrm{DC}$ 方式と呼ぶ)。このシステムは，インバー 
夕部の直流側に DC フィルタを必要とし，そこに用い られる直流りアクトルおよび電解コンデンサがシステ ムの小形化の新たな障害となるばかりでなく，電解コ ンデンサがシステム全体の寿命まで決めてしまう。ま た，このシステムでは電力の変換段数が多く効率が悪 くなる。

これに対し，Maniasらは，商用周波の交流電圧か ら直接高周波の交流電圧を得るシステム (SwitchMode-Rectifier, 以下SMRと略記）を提案している(2)。 この SMR は, $\mathrm{AC} \rightarrow \mathrm{DC} \rightarrow \mathrm{HF} \rightarrow \mathrm{DC}$ 方式に比べ, $\mathrm{AC} \rightarrow \mathrm{HF} \rightarrow \mathrm{DC}$ と変換段数が少なく，また $\mathrm{DC}$ フィ ルタを必要としないのでシステムの小形・軽量化が容 易であり，しかも高寿命・高効率を実現できる優れた システムである。Maniasらは，SMRの出力電圧制 御法の提案 ${ }^{(2)}$ も行っているが，この方法はコンバータ の PWM パターンとインバータの PWM パターンを 別々に発生させた後，信号処理の段階で仮想的に合成 しているため，任意の出力電圧波形を得ようとした場 合，リアルタイム制御が困難である。また，入力電流 に含まれる高調波成分の低減も十分でない。

青木らは $\mathrm{AC} \rightarrow \mathrm{HF}$ の变換部に単方向のスイッチ を用いた SMR について出力電圧制御法の検討を行っ ている(3)。この方法は, 線間電圧に比例して各線間電 圧の出力パルス幅を決めており，入力電流波形を正弦 波にすることが可能であり，双方向スイッチを用いた SMR に適用することも可能である。しかし，この方 法では制御法の定式化がなされておらず，リアルタイ ム制御が難しいと考えられ，また各サンプリングごと に，各線間電圧をすべて出力するのでスイッチング回 数が多くなっている。

本論文では，SMRの新しい制御法を提案する。提 案する制御法は，著者らが従来提案してきた PWM 制御サイクロコンバータの制御法 ${ }^{(4)(5)}$ の座標変換の考 え方に基づいている。本制御法は，SMRの制御法を 定式化するとともに，スイッチング回数を低減してい る。本制御法によれば，入力電流の高調波成分を低減
でき，入力力率を可変にできる。また，変圧器一次電 圧波形をリアルタイムで制御することが可能であり， 高周波変圧器の直流偏磁対策も容易に行える。

以下，提案する制御法を示し，次に本制御法の有用 性をシミュレーションにより確認し, 更に実験により 検証する。

\section{2. 主回 路}

図 1 (a) は SMR の主回路構成を示す。主回路は入 カ $l C$ フィル， 6 個の双方向スイッチ $S_{a u} \sim S_{b u}$, 高周波変圧器 $T$ および整流回路からなる。本回路で は, 電源と負荷の絶縁が, 高周波変圧器 $T$ に上り行 われている。双方向スイッチ $S_{a u} \sim S_{b w}$ には図1(b) に示すような逆阻止形自己消弧菜子を使用した。直列 素子数の点から逆阻止形 GTO を用いたものがよく， この場合には SMR の損失を $\mathrm{AC} \rightarrow \mathrm{DC} \rightarrow \mathrm{HF} \rightarrow \mathrm{DC}$ 方式と比べて小さくできる可能性がある。入力 $に C$ フ イルタは，スイッチングによる高周波電流を除去する ためであり，フィルタ用コンデンサ $C$ は静電容量の 小さなものでよい。フィルタ用インダクタンスlは電 源のインダクタンスを含むものとする。また抵抗 は電源放よびフィルタ用のリアクトルの抵抗とする。 負荷回路の $L, C_{0}$ は SMR の出力電圧に含まれる高調 波成分を除去するためである。

電源電圧, 電流をそれぞれ $v_{w 0}, v_{v 0}, v_{w 0}, i_{w 0}, i_{v 0}, i_{w 0}$ とし, 入力フィル夕後の電圧, 電流をそれぞれ $v_{u}, v_{v}$, $v_{w}, i_{u}, i_{v}, i_{w}$ とする。また，入力側中性点 $N$ からみた 出力電圧を $v_{a}, v_{b}$ とし, 変圧器 $T$ の一次巻線の電圧 を $v_{O H}$, 一次巻線を流れる電流を $i_{O H}$ とする。更に, 負荷抵抗 $R$ の電圧を $v_{\mathrm{DC}}$ とする。入力電圧 $v_{u v}, v_{v 0,}$ $v_{w 0}$ および入力フィル夕後の電圧 $v_{u}, v_{v}, v_{w}$ は次式て 表されるものとする。

$$
\left[\begin{array}{l}
v_{u 0} \\
v_{v 0} \\
v_{w 0}
\end{array}\right]=V_{s}\left[\begin{array}{l}
\cos \omega t \\
\cos (\omega t-2 \pi / 3) \\
\cos (\omega t+2 \pi / 3)
\end{array}\right] \cdots
$$

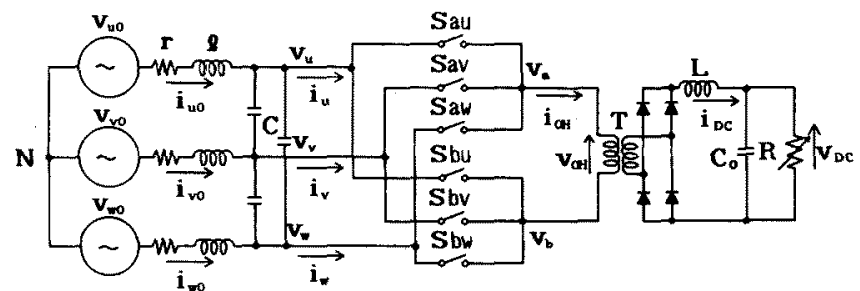

(a)主回路
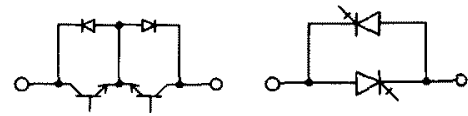

(b)スイッチ素子

図 1 高周波リンク形 AC-DC コンバータ (SMR)

Fig. 1. AC-DC converter with high-frequency link. 
$\left[\begin{array}{l}v_{u} \\ v_{v} \\ v_{w}\end{array}\right]=V\left[\begin{array}{l}\cos (\omega t-\delta) \\ \cos (\omega t-\delta-2 \pi / 3) \\ \cos (\omega t-\delta+2 \pi / 3)\end{array}\right]$

ここで, $\omega$ : 電源角周波数, $V_{s}$ : 電源電圧振

幅, $V:$ 入力フィルタ後の電圧振幅, $\delta:$ 入 カフィルタによって生じる位相遲れ角

\section{3. 制御方法}

〈3.1〉 制御関数 入力側に入力フィルタ用のコ ンデンサ $C$ が接続されているので，スイッチ $S_{a u}$ 〜 S b方ン・オフによりこのコンデンサを短絡する ことは許されない。また，スイッチの出力側に法高周 波変圧器 $T$ が接続されているので,この変圧器の一 次側を解放することは, 変圧器の漏れリアクトルによ る過大な電圧を吸収するためのスイッチのスナバ容量 の增大につながり好ましくない。そこで，スイッチ $S_{a w} \sim S_{b w}$ は, 図 2 に示すようにオン・オフ制御する。 リアルタイム制御を考慮して、スイッチングパターン はサンプリング周期 $T_{s}$ ごとに更新するものとする。 ここで，各スイッチに対して，制御関数を導入する。 制御関数 $a_{u} \sim b_{w}$ は，それぞれサンプリング周期 $T_{s}$ 内での各スイッチのオン時間の割合で与光られる。例 えば, $a_{u}$ については,

$$
a_{u}=\left(T_{s} \text { 内の } S_{a u} \text { のオン時間 }\right) / T_{s}
$$

のように定義される。他のスイッチについても同様で ある。図 2 より，これらの制御関数には次のような拘 束条件が与えられる。

$$
\begin{aligned}
& a_{u}+a_{v}+a_{w}=b_{u}+b_{v}+b_{w}=1 \\
& 0 \leqq a_{q} \leqq 1,0 \leqq b_{q} \leqq 1 \\
& \text { ただし............ }
\end{aligned}
$$

このとき， $N$ 点よりみた出力電圧 $v_{a}, v_{b} の T_{s}$ 期間内 の平均值 $\overline{v_{a}}, \overline{v_{b}}$ は, 制御関数と入力電圧 $v_{u}, v_{v}, v_{w}$ を 用いて，次のように表される。

$$
\left[\begin{array}{c}
\overline{v_{a}} \\
\overline{v_{b}}
\end{array}\right]=\left[\begin{array}{lll}
a_{u} & a_{v} & a_{w} \\
& & \\
b_{u} & b_{v} & b_{w}
\end{array}\right]\left[\begin{array}{l}
v_{u} \\
v_{v} \\
v_{w}
\end{array}\right]
$$

また, 入力電流 $i_{u}, i_{v}, i_{w}, の T_{s}$ 期間内の平均值 $\overline{i_{u}}, \overline{i_{v}}$,

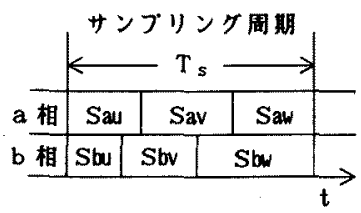

図 2 スイッチングパターン

Fig. 2. Switching pattern. $\overline{i_{w}}$ は, 高周波変圧器 $T$ の一次側の電流 $i_{O H}$ を用い て，次式のように表される。

$$
\left[\begin{array}{c}
\overline{i_{u}} \\
\frac{i_{v}}{i_{w}}
\end{array}\right]=\left[\begin{array}{ll}
a_{u} & b_{u} \\
a_{v} & b_{v} \\
a_{w} & b_{w}
\end{array}\right]\left[\begin{array}{c}
i_{O H} \\
\\
-i_{O H}
\end{array}\right]
$$

座標変換の考え方 ${ }^{(4)}$ に基づき，制御関数を次のよう に定める。

$$
\left.\begin{array}{l}
{\left[\begin{array}{l}
a_{u} \\
a_{v} \\
a_{w}
\end{array}\right]=A\left[\begin{array}{l}
X_{u} \\
X_{v} \\
X_{w}
\end{array}\right] Y_{a}+\left[\begin{array}{l}
h_{u} \\
h_{v} \\
h_{w}
\end{array}\right]} \\
{\left[\begin{array}{l}
b_{u} \\
b_{v} \\
b_{w}
\end{array}\right]=A\left[\begin{array}{l}
X_{u} \\
X_{v} \\
X_{w}
\end{array}\right] Y_{b}+\left[\begin{array}{l}
h_{u} \\
h_{v} \\
h_{w}
\end{array}\right]}
\end{array}\right\}
$$

ただし， $Y_{a}+Y_{b}=0$

ここで, $A$ は出力電圧の振幅を決定する指令值に相 当し, $h_{u}, h_{v}, h_{w}$ 注制御関数が ( 4 )式の抱束条件を満 足するように導入した関数である。関数 $X_{u}, X_{v}, X_{w}$ を次式で与える。

$$
\left[\begin{array}{l}
X_{u} \\
X_{v} \\
X_{w}
\end{array}\right]=\left[\begin{array}{l}
\cos \left(\omega t+\varphi_{s}\right) \\
\cos \left(\omega t+\varphi_{s}-2 \pi / 3\right) \\
\cos \left(\omega t+\varphi_{s}+2 \pi / 3\right)
\end{array}\right]
$$

ここで， $\varphi_{s}$ は入力電圧 $v_{u}, v_{v}, v_{w}$ に対する入力電流 $\overline{i_{u}}, \overline{i_{v}}, \overline{i_{w}}$ の位相差を決める指令值である。関数 $Y_{a}$ ， $Y_{b}$ は後に与える。(2)，(8)，(9)式を(6)式に代 入することにより， $T_{s}$ 期間内の出力電圧の平均值 $\overline{v_{a}}$, 儌は，次式のように与えられる。

$$
\left[\begin{array}{l}
\overline{v_{a}} \\
\overline{v_{b}}
\end{array}\right]=\frac{3}{2} A V \cos \left(\varphi_{s}+\delta\right)\left[\begin{array}{l}
Y_{a} \\
Y_{b}
\end{array}\right]+\left[\begin{array}{l}
v_{0} \\
v_{0}
\end{array}\right]
$$

ただし， $v_{0}$ は次式で表される。

$$
v_{0}=h_{u} v_{u}+h_{v} v_{v}+h_{w} v_{w}
$$

従って, 高周波変圧器一次側の電圧 $v_{O H}$ のサンプり ング周期 $T_{s}$ 内の平均値 $\overline{v_{O H}}$ は

$$
\begin{aligned}
\overline{v_{O H}} & =\overline{v_{a}}-\overline{v_{b}} \\
& =\frac{3}{2} A V \cos \left(\varphi_{s}+\delta\right)\left(Y_{a}-Y_{b}\right)
\end{aligned}
$$

となる。直流出力電圧 $v_{\mathrm{DC}}$ は, $v_{\mathrm{OH}}$ を整流, 平滑した 值であるので，(12)式より $(8)$ 式の $A$ の值が直流出 力電圧 $v_{\mathrm{DC}}$ を決めることがわかる。また(10)，(12)式 より (8)式において導入した関数 $h_{u}, h_{v}, h_{w}$ による出 力電圧恬零相電圧成分となり, 高周波変圧器の印加電 圧には現れないこともわかる。高周波変圧器 $T$ の一 次側のサンプリング周期 $T_{s}$ 内の平均電圧 $\overline{v_{O H}}$ には, 関数 $Y_{a}, Y_{b}$ の差の波形がそのまま表れるので, これ らの関数が出力電圧波形の指令值となる。そこで, 関 
数 $Y_{a}, Y_{b}$ を出力関数と呼ふ。この出力関数には任意 の関数を選択できるが， $\overline{v_{O H}}$ をサンプリング周期 $T_{s}$ ごとに正負の反転する方形波出力とすることにより， 同一のリンク周波数でスイッチング周波数を最も低減 でさる。そのときの関数 $Y_{a}, Y_{b}$ 岻次式で与えられる。

$$
\left[\begin{array}{l}
Y_{a} \\
Y_{b}
\end{array}\right]=\left\{\begin{array}{rr}
{\left[\begin{array}{r}
1 \\
-1
\end{array}\right]} & \left(\sin \omega_{0} t \geqq 0 \text { のき }\right) \\
{\left[\begin{array}{r}
-1 \\
1
\end{array}\right]} & \left(\sin \omega_{0} t<0 \text { のと }\right)
\end{array}\right.
$$

$$
\text { ただし， } \omega_{0} \text { : 出力電压 } v_{O H} \text { の角周波数 }
$$

直流出力電流 $i_{\mathrm{DC}}$ がリプルを含まず, $i_{\mathrm{DC}}=I$ (一定

值）とするとき，高周波変圧器の一次側電流は,

$$
i_{O H}=I\left(Y_{a}-Y_{b}\right) / 2
$$

となる。このとき, 入力電流 $i_{u}, i_{v}, i_{w}$ のサンプリン 妿周期 $T_{s}$ 内の平均值 $\overline{i_{u}}, \overline{i_{v}}, \overline{i_{w}}$ は， (8)，(9), (13)，(14)式を(7)式に代入することにより，

$$
\begin{aligned}
{\left[\begin{array}{l}
\overline{i_{u}} \\
\overline{i_{v}}
\end{array}\right] } & =2 A I\left[\begin{array}{l}
X_{u} \\
X_{v} \\
X_{w}
\end{array}\right] \\
& =2 A I\left[\begin{array}{l}
\cos \left(\omega t+\varphi_{s}\right) \\
\cos \left(\omega t+\varphi_{s}-2 \pi / 3\right) \\
\cos \left(\omega_{t}+\varphi_{s}+2 \pi / 3\right)
\end{array}\right]
\end{aligned}
$$

と与文られ，正弦波となる。 $\varphi_{s}$ は (9)式に拁いて導 入した值であり自由に設定できるので， $\overline{i_{u}}, \overline{i_{w}}, \overline{i_{w}}$ の 位相指令値となることがかかる。以下，関数 $X_{u} \sim X_{w}$ を入力関数と呼ぶ。

\section{〈3・2〉，スイッチング回数の低滅と最大出力電圧}

次に, $h_{u}, h_{v}, h_{w}$ の決め方拈よび $A$ の最大值につい て述べる。

ある時刻 $t$ において, 出力関数 $Y_{a}, Y_{0}$ のうち大き いほうを $\max Y_{p}$ ，小さいほうを $\min Y_{p}$ とすると， (5)，(8)式上り $h_{t}, h_{v}, h_{w}$ の制約条件が次に示吉上 うに与えられる。

$-A X_{q} \min Y_{p} \leqq h_{q} \leqq 1-A X_{q} \max Y_{p}$

$$
\left(X_{q} \geqq 0\right)
$$

$\left.-A X_{q} \max Y_{p} \leqq h_{q} \leqq 1-A X_{q} \min Y_{p}\right\}$

$$
\begin{array}{r}
\left(X_{q}<0\right) \\
(q=u, v, w)
\end{array}
$$

また，(4)，（8)式より

$$
h_{u}+h_{v}+h_{w}=1
$$

の関係がある。

文献 (3)の制御法では $u-v, v-w, w-u$ の各線間電 圧を毎サンプリング期間出力しているが，すべての線 間電圧を一つのサンプリング期間内に出力するとスイ

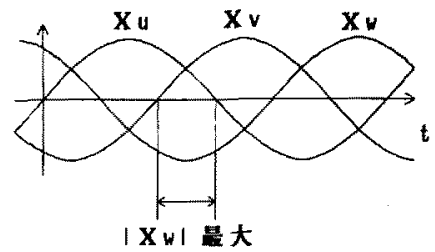

(a) 入力関数

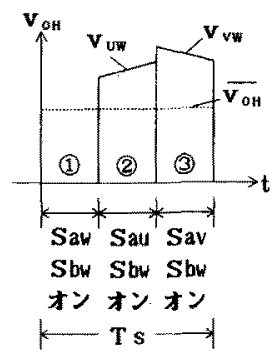

(b) V O 0 拉大国

図 3 スイッチング回数の少ないスイッチングの例 Fig. 3. Example of switching sequence with small switching frequency.

ッチング回数が多くなってしまう。

いま，ある $T_{s}$ 期間中において， $X_{u}, X_{v}, X_{w}$ の入力 関数のうち， $X_{w}$ の絶対值が最大でかつ負の值であ りまた $Y_{a}=1 ， Y_{b}=-1$ である場合を考える。この とき， $S_{b w}$ を $T_{s}$ 期間中常にオンとして $S_{b u}, S_{b v}$ 虹入 イッチングを行わないようにし, 出力電圧は $S_{a u}, S_{a v}$, $S_{a w}$ のオン期間により制御すればスイッチング回数を 低滅できる。この様子を図 3に示す。(a)図に示す

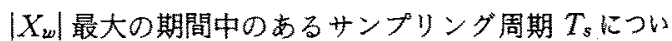
て, 高周波変汪器 $T$ の一次電圧 $v_{\text {OH }}$ の波形を横朝 $t$ を应大して(b)図に示す。出力電圧 $v_{O H}$ は、 $a$ 相と $b$ 相がともに $w$ 相につながった電圧雾の状態（図中(1) と, $u-w$ 相間の線間電圧 $v_{u w}$ が出力されている状態 (2)）おるび $v-w$ 相間の線間電圧 $v_{v w}$ が出力されてい る状態（(3) からなり，この三つの状態により平均出

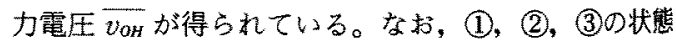
の順序には自由度が残されているが， $T_{s}$ 期間内の最 初に出力電圧抽よび入力電流を 0 にするスイッチンタ 状態（1)の状態）がくるようにスイッチング順序を決 めると，各モード間の遷移時にスイッチングの切換え がスムーズに行われ，出力電圧波形，入力電流波形の ひずみを抑えることができる(5)。図 3(b)の場合，ス イッチ素子のオン順序（以下，スイッチング順序と略 記）は，記号の右下添字の順で示すと $w \rightarrow u \rightarrow v$ となる。 以上のスイッチングを実現する関数 $h_{u}, h_{v}, h_{w}$ およ 
表 $1 h_{u}, h_{v}, h_{w}$ とスイッチング順序の例 Table. 1 Example of $h_{u}, h_{v}, h_{w}$ and switching sequence.

\begin{tabular}{|c|c|c|c|c|c|c|}
\hline$\epsilon-R^{\circ}$ & 1 & 2 & 3 & 4 & 5 & 6 \\
\hline$X_{u}$ & + & + & - & - & - & + \\
\hline$\overline{\mathbf{X}_{v}}$ & - & + & + & + & - & - \\
\hline $\mathrm{X}_{u}$ & - & - & - & + & + & + \\
\hline$h_{y}$ & $\begin{array}{c}1-A X_{u} \\
\times \max Y_{p}\end{array}$ & $\begin{array}{c}-A X_{u} \\
\times \min Y_{\rho}\end{array}$ & $\begin{array}{c}-A X_{u} \\
\times \max Y_{p} \\
\end{array}$ & $\begin{array}{r}1-A X_{u} \\
\times \min Y_{\rho}\end{array}$ & $\begin{array}{c}-A X_{u} \\
\times \max Y_{p}\end{array}$ & $\begin{array}{l}-A X_{u} \\
\times \min Y_{\rho}\end{array}$ \\
\hline $\mathbf{h}_{v}$ & $\begin{array}{c}-A X_{v} \\
\times \max Y_{s}\end{array}$ & $\mid \begin{array}{c}-A X_{v} \\
\times \min Y_{p}\end{array}$ & $\begin{array}{l}1-A X_{v} \\
\times \max Y_{\phi}\end{array}$ & $\begin{array}{c}-A X_{0} \\
x_{\min } Y_{\circ}\end{array}$ & $\begin{array}{c}-A X_{v} \\
\times \max Y_{p}\end{array}$ & $\begin{array}{l}1-A X_{v} \\
\times \min Y_{\beta}\end{array}$ \\
\hline $\mathrm{h}_{w p}$ & $\begin{array}{r}-A X_{w} \\
x_{\max Y_{p}} \\
\end{array}$ & $\begin{array}{c}1-A X_{\nu} \\
\times \min Y_{\nu}\end{array}$ & $\begin{array}{c}-A X_{w} \\
\times \max Y_{p}\end{array}$ & $\begin{array}{c}-A X_{L t} \\
\times \min Y_{p}\end{array}$ & $\begin{array}{l}1-A X_{w} \\
\times \max Y_{\phi}\end{array}$ & $\begin{array}{r}-A X_{w} \\
\times_{\min } Y_{p} \\
\end{array}$ \\
\hline $\begin{array}{c}\text { スイッキン } \\
\text { 顷序 }\end{array}$ & & $u \rightarrow u \rightarrow v$ & $u \rightarrow u \rightarrow u$ & $u \rightarrow v \rightarrow u$ & $w \rightarrow u \rightarrow v$ & $v \rightarrow w \rightarrow u$ \\
\hline
\end{tabular}

びスイッチング順序を表 1 に示す。 $X_{u}, X_{v}, X_{w}$ の絶 対值がそれぞれ最大となる場合により六つのモードが 存在する。出力関数 $Y_{a}, Y_{b}$ が(13)式で与えられる場 合には, $\max Y_{p}=1, \min Y_{p}=-1$ となり表 1 は簡単 になる。このとき, 平均出力電圧 $v_{O H}$ を毎サンプリン グー定に制衔できる $A$ の值の範囲恃

$0 \leqq A \leqq 1 / 2$

となる。従って, $\overline{v_{O H}}$ の最大值は，(12)式により, $(3 / 2) V \cos \left(\varphi_{s}+\delta\right)$ となる。 $\varphi_{s}=0$ (入力力率 $\fallingdotseq 1 の$ とき)，V $\cos \delta \fallingdotseq V_{s}$ とすれば出力電圧 $\overline{v_{O H}}$ は電源相 電圧の振幅の 1.5 倍まで出せることになる。

〈3.3〉 変圧器の直流偏磁の抑制以上で述べて きた制御アルゴリズムを実現する際に考慮しなければ ならない問題点の一つに高周波変圧器 $T$ の直流偏磁 の問題がある。この問題について以下に考察する。

まず, 出力電流極性判別回路および電源短絡防止用 のデッドタイムの必要性について述べる。図 1 に极い て，簡単のため入力フィルタを無視する。いま， $v_{u 0}$ $>v_{v 0}, i_{O H}>0 て ゙ S_{a u}$ から $S_{a v}$ へとスイッチを切換元 る場合を考えると， $S_{a u}$ をオフた後デッドタイムを 設けて $S_{a v}$ をオンすると，デッドタイムの期間は出力 開放となるのでスナバ回路の容量增大を招く。ところ で,スイッチ $S_{a u}, S_{a v}, S_{a w}$ は図1(b)に示したような 逆阻止形自己消弧素子が実用的である。図 4 はスイッ 于 $S_{a u}, S_{a v}, S_{a w}$ をそれそれれつの逆阻止形自己消弧 素子 $S_{a u}{ }^{+}, S_{a u}{ }^{-}, S_{a v}{ }^{+}, S_{a v}{ }^{-}, S_{a w}{ }^{+}, S_{a w}{ }^{-}$で置き換えた $a$ 相の等洒回路を示す。文献 $(6)$ では, 電源電圧の極 性に応じてスイッチ $S_{a u}{ }^{+}, \cdots, S_{a w}{ }^{-}$のうち二つを常に オンとしてフィードバックダイオードの働きをさせ, 出力開放を防止しているが, 転流の際に制御関数で定 義されない期間にこのフィードバックダイオードを通 して電流が流れるので，入力電流波形を大きくひずま

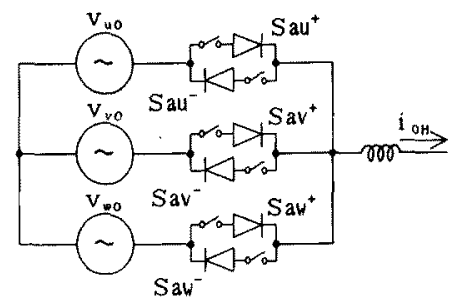

図 $4 \mathrm{SMR}$ の $a$ 相分の等価回路

Fig. 4. Equivalent circuit of $a$-phase of SMR.

せ好ましくない。そこで，本論文では以下の方法を用 いることとした。図 4 の回路において， $i_{O H}>0$ のと きに $S_{a u}{ }^{+}$から $S_{a v}{ }^{+}$人とスイッチを切換光れば， $S_{a u}{ }^{+}$ の蓄積時間により $S_{a u}{ }^{+}$と $S_{a v}{ }^{+}$が同時にオン状態とな る期間が存在しても, スイッチの逆阻止能力に上り電 源短絡は起きない。同様にして， $v_{u 0}<v_{v 0,} i_{O H}<0 て$

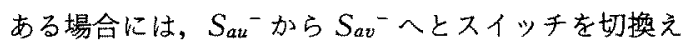
ればよい。以上のスイッチングを実現するために出力 電流極性判別回路が必要になる。本方法においてもデ ッド夕イムは必要である。例えぱ, $v_{u 0}>v_{v 0}, i_{O H}>0$ で, $S_{a u}{ }^{+}$から $S_{a v}{ }^{+}$ヘスイッチを切換える場合を考え る。 $S_{a u}{ }^{+}$がオフする瞬間に電流極性判別回路が動作 すると， $S_{a u}{ }^{+}$が十分オフ状態にならないうちに $i_{O H}<$ 0 の電流を流そうとして $S_{a v}{ }^{-}$がオンとなり, 電源短 絡が起きてしまう。そこで，湔が零となった後に電 源短絡防止用のデッドタイム $T_{d}$ を設ける。

次に, 高周波変圧器一次側巻線の出力電生 $v_{O H}$ の極 性が切換わるときの, 出力電流 $i_{O H}$ について考える。 $Y_{a}=1, Y_{b}=-1$ であるサンプリング期間から， $Y_{a}=$ $-1, Y_{b}=1$ となるサンプリング期間へ移行するとき, 出力電圧 $v_{O H}$ はいったん零になる(図 3(b)の(1)の期 間に相当する】。この間, 出力電流 $i_{O H}$ は高周波変圧 器の漏れインダクタンスにより, スイッチ $S_{a u}$ (もし く蛙 $\left.S_{a v}, S_{a w}\right)$ と $S_{b u}\left(\right.$ もしくは $\left.S_{b v}, S_{b w}\right)$ おうよ゙変 圧器の一次巻線の間を環流し続け, 高周波変圧器の巻 線抵抗およびスイッチ素子のオン電圧のロスにより 徐々に減衰する。出力電圧指令值 $A$ が小さいときは, 出力電圧が零である期間が長いため，この期間内に出 力電流 $i_{O H}$ が零になり電流極性判別回路によりスイッ 于の切換えが行われるので, 出力平均電圧 $\overline{v_{O H}}$ に変化 はない。しかし，出力電圧指令值 $A$ が大きくなると， 出力電流 $i_{O H}$ が零にならないうちに次の線間電圧が出 力されてしまう。この瞬間, 高周波変圧器の漏れイン ダクタンスのもつエネルギーは電源に回生され，i は急速に隇衰して零になる。その後で電流極性判別回 路が動作し，各スイッチを切換えるが，この切換えの 際にデッドタイム $T_{d}$ の期間は出力電圧 $v_{O H}$ が雾にな

電学論D, 110 巻 5 号, 平成 2 年 
る。このときの $v_{\mathrm{OH}}$ と $i_{\mathrm{OH}}$ の波形の様子を図 5 に示す。

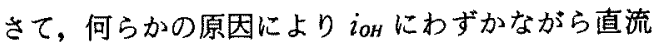
分が含まれていたとする。出力電圧指令值 $A$ をある 程度以上大きくすると， $i_{O H}$ が直流分と同極性のと き， $i_{0 H}$ が零になる以前に次のサンプリング周期にお ける線間電圧が出力されてしまい，このサンプリング 周期における出力電圧はデッドタイム $T_{d}$ の影響を受 ける。 $i_{O H}$ が直流分と逆極性のときは, $i_{O H}$ が完全に 零になってから次のサンプリング周期における線間電 圧が出力されるのて，このサンプリング周期はデッド タイム $T_{d}$ の影響を受けない。この結果, $i_{O H}$ が直流 分と逆極性のときに出力電圧 $\overline{v_{O H}}$ は $T_{d}$ の分たけ小さ くなるので, 結果として出力電流 $i_{O H}$ の直流分に正帰 摆がかかってしまう。

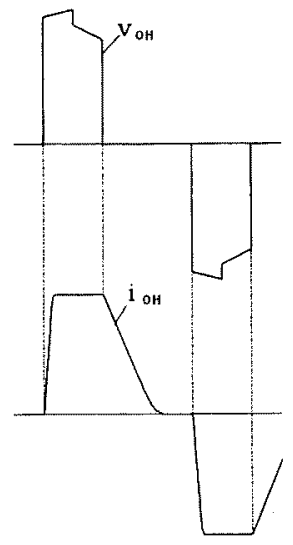

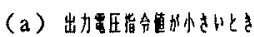

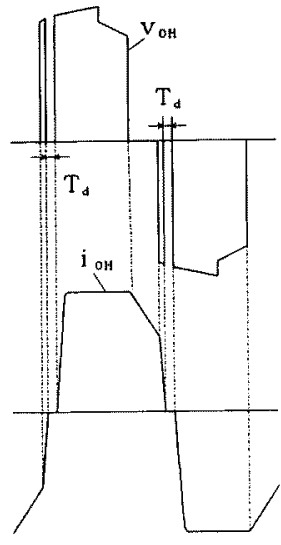

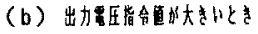

図 5 変圧器一次側の電圧・電流波形の概念図 Fig. 5. Waveforms of voltages and currents of primary winding of transformer.

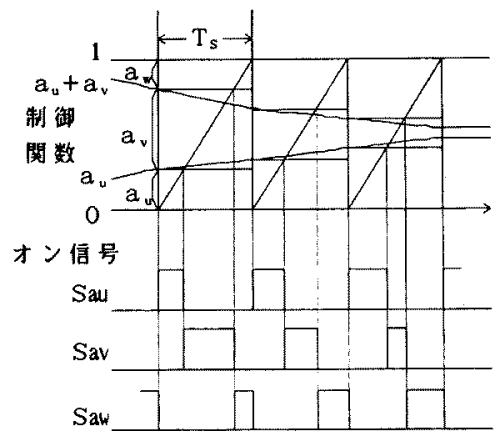

図 6 スイッチングパターンの作成法

Fig.6. Generation method of switching patterns. そこて，i $i_{O H}$ に含まれる直流成分を検出し，この值を用いて出 力関数 $Y_{a}, Y_{b}$ を補正する。このようにして，高周波 変圧器 $T$ の直流偏磁を防ぐことができる。

\section{4. シミュレーション}

図 6 は，（8)式で与えられた制御関数から実際に各 スイッチ素子のオン信号を作成する方法を示す。制御 関数 $a_{u}$ と $a_{u}+a_{v}$ の值をサンプリング期間 $T_{8}$ の間保 持し, サンプリング期間に同期したのこきり波と比較 することによって，オン信号 $S_{a u} \sim S_{a w}$ を得る。同栐 にして, 制御関数 $b_{u}, b_{u}+b_{v}$ よりオン信号 $S_{b u} \sim S_{b u}$

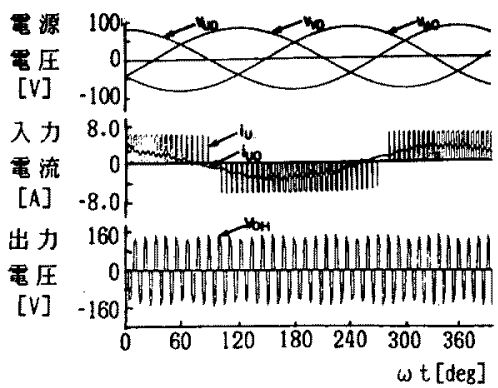

(a) $\mathrm{A}=1 / 4$

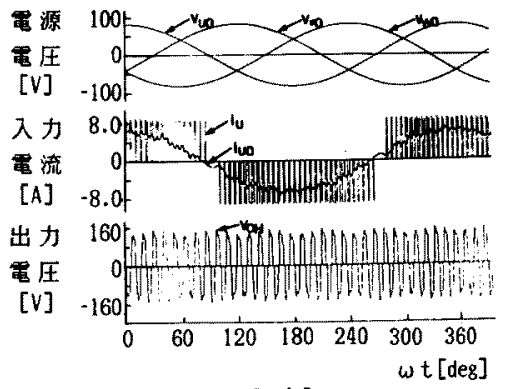

(b) $A=3 / 8$

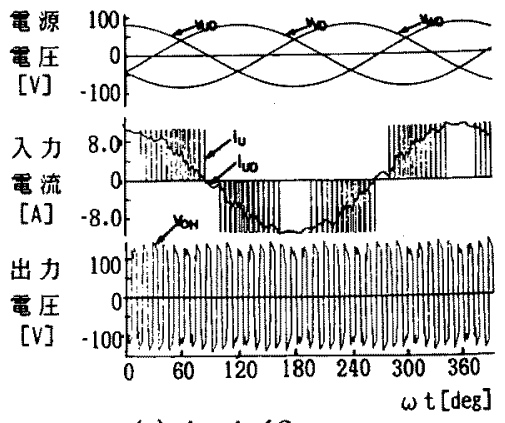

(c) $A=1 / 2$

図 7 シミュレーション結果

Fig. 7. Simulation results. 
を得る。この場合，スイッチング順序は記号の右下添 字の順ですと $u \rightarrow v \rightarrow w$ となるが，保持する関数を 変无ることにより，スイッチング順序を変えることが できる。例えば， $a_{v}, a_{v}+a_{w}$ を用いれば，スイッチ ング順序は $v \rightarrow w \rightarrow u$ となる。

図 7 は, (a) $A=1 / 4$, (b) $A=3 / 8$, (c) $A=$ $1 / 2$ とした場合のシミュレーション結果を示す。サン プリング周期は電源周期の 1/64 とした。このとき, 出力周波数は, 電源周波数の 32 倍 $(60 \mathrm{~Hz} \times 32=$ $1.92 \mathrm{kHz})$ になる。シミュレーションの条件を表 2 に示す。今回は, 提案した制御法の妥当性を調べるこ とを目的としており，負荷側の平滑コンデンサ $C_{0}$ は 出力電圧 $v_{\mathrm{bc}}$ がスイッチングによるリプルを含まない よう十分大きな值とした。また，スイッチは理想的な ものとし，電源短絡防止用のデッドタイムは設けなか つた。図 7 (a)〜 ( c)のいずれの場合も，電源電流

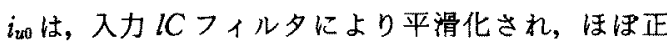
弦波に近い波形となっている。また，その位相は電源 電圧 $v_{u 0}$ と比べて, 入カフィルタコンデンサ $C$ によ

表 2 シミュレーション・実験で用いたパラメータ Table 2. Parameters of simulations and experiments.

\begin{tabular}{ll}
\hline 入力線間電压 & $: 100 \mathrm{~V}$ \\
㲠源周波数 & $: 60 \mathrm{~Hz}$ \\
出力周波数 & $: 1.92 \mathrm{kHz}$ \\
入力電流位相指令值 & $: \phi_{s}=0$ \\
高周波变圧器の卷数比 & $: 1: 1$ \\
& \\
入力フィルタ & 負䓵 \\
$r=0.5 \Omega$ & $R=10 \Omega$ \\
$l=0.6 \mathrm{mH}$ & $L=20 \mathrm{mH}$ \\
$C=10 \mu \mathrm{F}$ & $C_{0}=4,400 \mu \mathrm{F}$ \\
\hline
\end{tabular}

る分だけ進んでいる。出力電圧 $v_{\text {OH }}$ のパルスの幅は, そのサンプリングごとの平均值が一定となるように制 御されている。

\section{5. 実 験 結 果}

図 8 は，(8)式の制御関数を実現するために試作し た制御回路の構成を示す。

まず，PLL 回路を用いて電源電圧の電気角 $\theta$ を求 め, これと入力電流の位相指令值 $\varphi_{s}$ を基に, テーブ ルを用いて入力関数 $X_{u}, X_{v}, X_{w}$ を生成する。一方, PLL 回路の出力として得られる電気角 $\theta+\varphi_{s}$ を定数 倍（このシステムでは 32 倍）して, 出力電圧の電気 角 $\theta_{0}$ を得る。これと出力電圧の振幅の指令值 $A$ を用 いて, 出力側関数 $Y_{a}, Y_{b}$ を得る。更に, 表 1 を用い $\tau h_{u}, h_{v}, h_{w}$ を発生させ，(8)式の制御関数 $a_{u} \sim b_{w}$ を演算する。ここで， $a_{u} \sim b_{w}$ が(4)，(5)式の拘束 条件を満たしていない場合、リミッ夕をかけて条件を 満たすようにする $\left(L a_{u} \sim L b_{w}\right)_{\text {。 }}$ 最後に前章で述べた ようにのこぎり波比較を行って，オン信号 $S_{a u} \sim S_{b w}$ を得る。破線内の処理は 16 ビットマイクロプロセッ サ（MC 68000）に上って行った。

図 9 は, 本実験装置で設けた直流偏磁抑制回路を示 す。ホール素子により出力電流 $i_{O H}$ を検出した後, 一

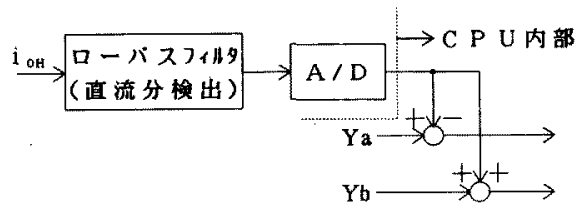

図 9 直流偏磁抑制回路

Fig. 9. Circuit for DC demagnetization.

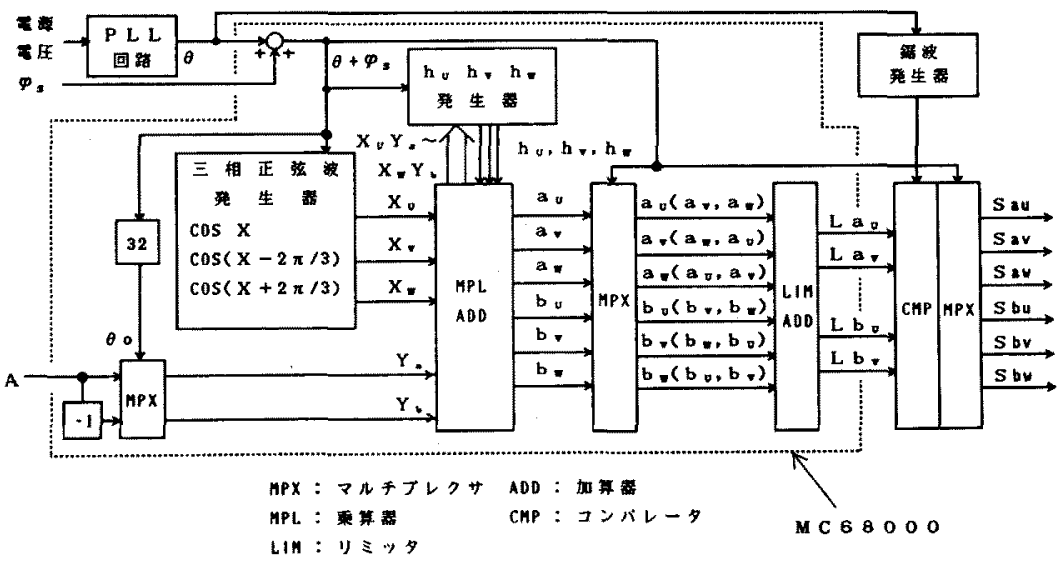

図 8 制御回路の構成

Fig. 8. Configuration of control circuit. 


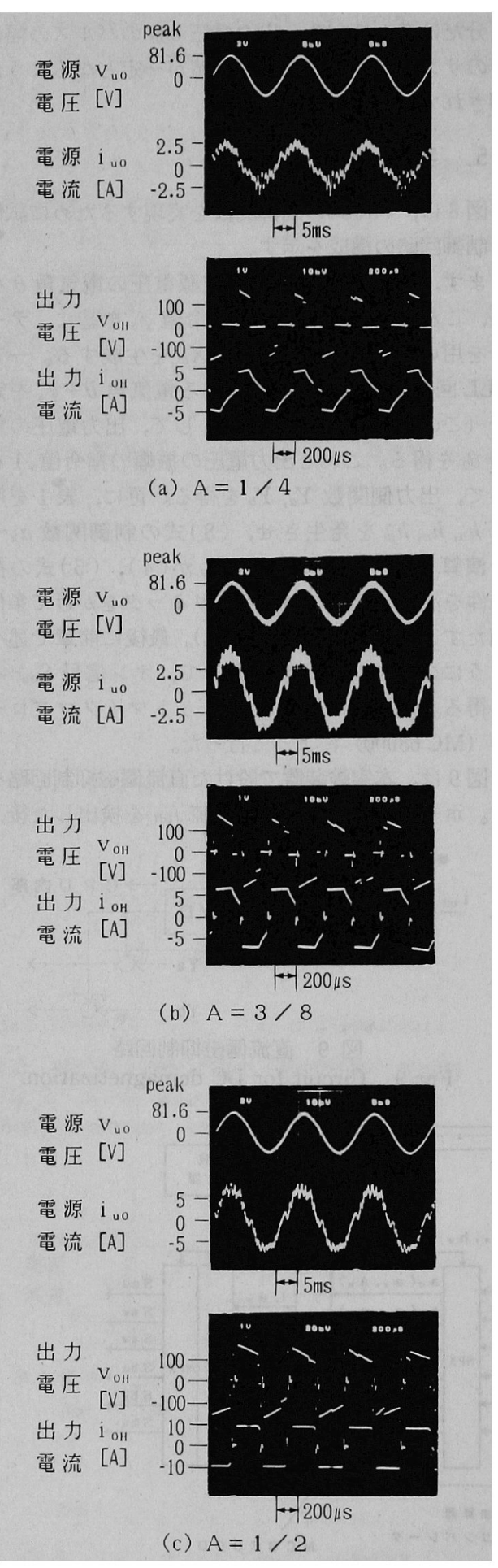

図 10 実験結果

Fig. 10. Experimental results.
次の低域フィルタにより $i_{O H}$ に含まれる直流分を取出 す。この值を $\mathrm{A} / \mathrm{D}$ 変換した後, CPU 内部に取込み, 出力関数 $Y_{a}, Y_{b}$ を補正している。この制御ループは 比例制御となっている。

図 10 に実験結果を示す。スイッチ素子としては, 図 1 (b)の 2 個のバイポーラトランジス夕による双方 向スイッチを用いた。高周波変圧器 $T$ の一次側電流 $i_{O H}$ の極性判別回路により，2 個のバイポーラトラン ジスタのうち一つをスイッチングさせるようにした。 図 10 (a) は出力電圧指令値 $A=1 / 4$, (b) は $A=$ $3 / 8$, (c ) は $A=1 / 2$, の場合の結果である。他の実 験条件はシミュレーションの条件と同じである。出力 電流 $i_{O H}$ は出力電圧 $v_{O H}$ の極性反転時に急速に零に落 ちている。また, その直後の $v_{\text {Oн }}$ はデッドタイム $T_{\mathrm{d}}$ により零となっている。本実験では $T_{d}=20 \mu \mathrm{s}$ とし た。直流偏磁抑制回路により, 安定な運転を実現する ことができた。電源電流 $i_{u 0}$ はシミュレーションと比 較してリプルが大きくなっているが，これは主にデッ ドタイムの影響による。実際に得られた直流出力電圧 は指令值に比べて若干低くなっているが，これはデッ ドタイムによる減少分のほかに, 本実験で用いた高周 波変圧器 $T$ と直流リアクトル $L$ が, 高周波用として 設計されたものでなかったことによる。

\section{6. まと め}

高周波リンク形 AC-DC コンバータ（SMR）の制 御法を検討し，座標変換の考え方に基づいた，新しい 制御法を提案した。その結果次の結論を得た。

（1）本制御法によれば, SMRのスイッチング回 数を従来方式より低減できることを示した。

(2) 変圧器の一次側電圧の最大出力電圧は入力相 電圧の $3 / 2$ であることがわかった。このとき直流出力 電圧は最大となる。

（3）本制御法により，入力電流をほほ力率 10 正 弦波にすることができた。

（4）本制御法は, 変圧器一次側電圧の出力電圧波 形をリアルタイムで制御することが容易であり, 従っ て高周波変圧器の直流偏磁対策も容易に実現できる。 直流出力電圧の制御も容易である。

（5）シミュ.レーションならびに実験により本制御 法の有用性を確認した。

なお，本論文ではスイッチ素子としてパワートラン ジスタを用いたためスイッチング周波数を $1.92 \mathrm{kHz}$ と低く設定した。スイッチ素子にIGBT を用いれば, スイッチング周波数を 10〜 $20 \mathrm{kHz}$ とし，出力容量を 数 $\mathrm{kW}$ 数十 $\mathrm{kW}$ とすることが可能であり, 高周波 
変圧器の一層の小形化が図れると共に, デッドタイム による入力電流の波形ひずみを改善できることが期待 される。

本論文で提案した制御法は, 変圧器一次側電圧制御 を出力関数 $Y_{a}, Y_{b}$ により容易に行えるので, 電源電 圧の不平衡, デッドタイムの補償も可能である。これ らについては誌面の関係から別の機会に報告したい。

(平成元年 3 月 27 日受付)

$$
\text { 文献 }
$$

（1）電気学会半導体電力変換方式調査専門委員会編：半導体電力 変換回路（昭 62）オ一公社

(2) S. Manias \& P. D. Ziogas: "A Novel Sinewave Method in $\mathrm{AC}$ to DC Converter with High-Frequency Transformer Isolation", IEEE Trans. Industr. Electr., IE-32, 430 (1985)

（3）青木·五十嵐・锹田・大橋：「三相交流電圧直接変換形整流器」, 昭 63 電気学会全大, No.582

(4) 石田・岩崎・大熊・岩田:「入力力率可変正弦波入出力 PWM 制御+イクロコンバータの波形制御法」, 電学論 D, 107, 239 (昭 62-2)

（5）岩崎・石黑・石田・金・大熊・岩田：「PWM 制御莳イロコ ンバータのスイッチングパターン作成法」, 同上 D, 109 , 82 (平元 -2$)$

(6) 石黒・石田・大熊・内川・岩田：「PWMサイクロコンバー夕 の出力電流波形の改善」, 第 74 回パワーエレクトロニクス研 资, p.96

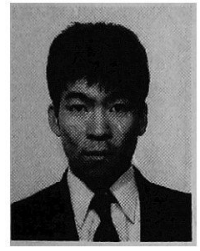

\section{稲 垣 克 久 (正員)}

昭和 40 年 10 月 25 日生。 63 年 3 月名古屋大学工学部電気学科卒業。 同年 4 月同大学大学院工学研究科博 士前期課程電気工学・電子工学専攻 に進学, 現在に至る。主として, 高周波リンク形電力 変換器に関する研究に従事。

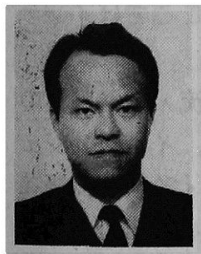

\section{古橋武（正員）}

昭和 29 年 12 月 11 日生。 60 年 3 月名古屋大学大学院博士課程修了。 工学博士。同年 10 月 (株) 東芝入社。 府中工場において GTO PWM イン パータの研究, 開発に従事。63 年 4 月名古屋大学工 学部電子機械工学科助手, 現在に至る。主として, パ ワーエレクトロニクス, アドバンテスモーションコン トロールおよびニューロ・ファジーに関する研究に従 事。IEEE, 計測自動制御学会会員。

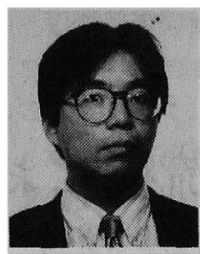

\section{石 黒 章 夫（正員）}

昭和 39 年 5 月 18 日生。平成元年 3 月名古屋大学大学院工学研究科博 土前期課程電子機械工学専攻修了。 同年 4 月同後期課程に進学，現在に 至る。主として, PWM 制御サイクロコンバー夕に関 する研究に従事。IEEE，バイオメカニズム学会会員。

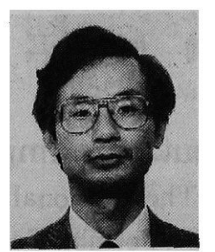

\section{石田宗 秋 (正員)}

昭和 27 年 4 月 12 日生。 55 年 3 月名古屋大学大学院博士課程修了。 62 年 6 月三重大学工学部電気工学 科助教授, 現在に至る。工学博士。 主として, 誘導電動機の制御, 小形モー夕の開発およ び制御，PWM 制御サイクロコンバータに関する研究 に従事。IEEE, パワーエレクトロニクス研究会, 計 測自動制御学会会員。

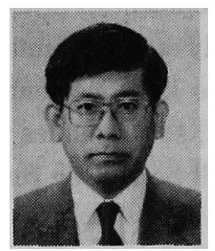

\section{大 熊 正員)}

昭和 23 年 2 月 16 日生。 49 年 6 月ケース・ウェスターン・リザーブ 大学大学院工学研究科修士課程シス テム工学専攻修了。 52 年 3 月名古 屋大学大学院博士課程満了。59 年 4 月同大学助教授, 現在に至る。工学博士。主として, パワーエレクトロ ニクス, ロボティクス, マイクロメカトロニクス, 二 ユーロファジーの研究に従事。IEEE, 計測自動制御 学会, 日本ロポット学会, パワーエレクトロニクス研 究会会員。

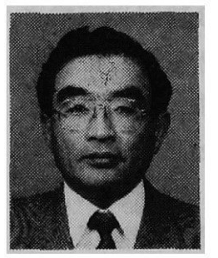

\section{内 川 嘉 樹 (正員)}

昭和 16 年 8 月 4 日生。 44 年 3 月 名古屋大学大学院博士課程満了。 53 年, 同大学助教誘授, 60 年同教授, 現在に至る。工学博士。CAD, 画像 処理，信号処理などを対象としたシステム技術の基礎 および産業への応用に関する研究に従事。61 年日本電 子顕微鏡学会論文賞受賞。日本電子顕微鏡学会, 応用 物理学会, 精密工学会, 計測自動制御学会, 境界要素 法学会, 日本ロポット学会会員。 